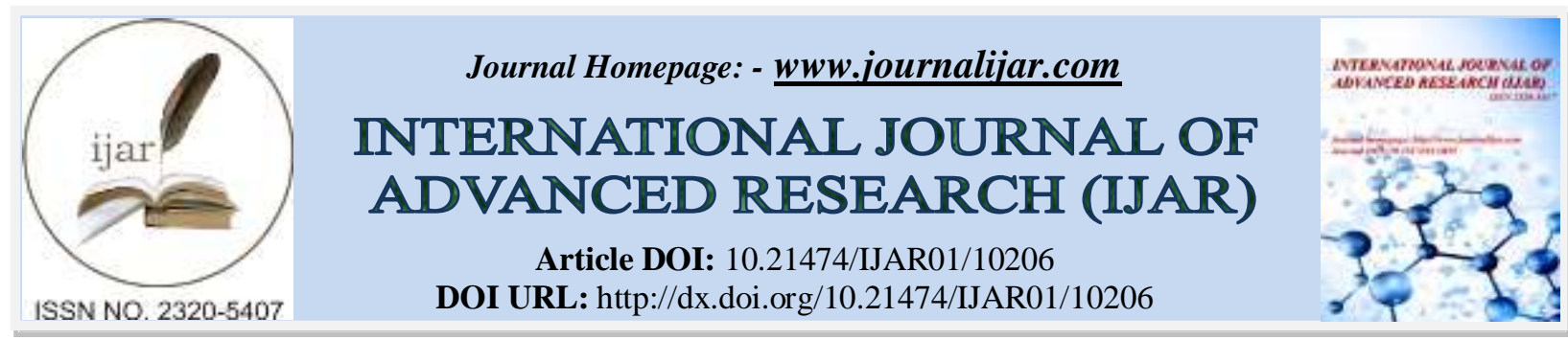

RESEARCH ARTICLE

\title{
PHYTOCHEMICAL SCREENING AND IN VITRO EFFECT OF WATERY TRITURATED EXTRACT OF MITRAGYNA INERMIS (WILLD.) KUNTZ (RUBIACEAE) ON HAEMONCHUS CONTORTUS
}

Toklo Placide Mahougnan ${ }^{1,2}$, Yayi Eléonore ${ }^{1}$, Sakirigui Amoussatou ${ }^{1,3}$, Alowanou Goué Géorcelin ${ }^{2}$, Assogba Mahoudo Fidèle ${ }^{1}$, Kakpo Blandine ${ }^{1}$, Hounzangbé-Adoté Sylvie ${ }^{2}$ and Gbenou Joachim Djimon ${ }^{1,3^{*}}$

1. Laboratoire de Pharmacognosie et des Huiles Essentielles, Facultés des Sciences et Techniques, Université d'Abomey Calavi, 01 BP : 918 ISBA Cotonou, Bénin.

2. Laboratoire d'Ethnopharmacologie et de Santé Animale, Faculté des Sciences Agronomiques, Université d'Abomey Calavi, 01 BP : 526 Cotonou, Bénin.

3. Laboratoire de Recherche sur les Plantes à Parfums, Aromatiques, Alimentaires et Médicinales Faculté des Sciences et Techniques, UNSTIM d'Abomey, BP : 72 Natitingou, Benin.

\section{Manuscript Info}

\section{Manuscript History}

Received: 10 October 2019

Final Accepted: 12 November 2019

Published: December 2019

Key words:-

Mitragyna inermis, Anthelmintic

Properties, Phytochemical Screening,

Haemonchus contortus, Toxicity

\begin{abstract}
Mitragyna inermis is a plant widely used by breeders in the control of small ruminants. The objective of this study is to evaluate the anthelmintic properties of the watery triturated extract of the leaves of this plant on Haemonchus contortus, a severe parasite of small ruminants in Benin. The best results are obtained with the inhibition of larval migration and motility of adult worms. The watery triturated extract of the plant significantly inhibited larval migration $(\mathrm{p}<0.001)$ and motility of adult worms $(\mathrm{p}<0.001)$ in $H$. contortus. This justifies these anthelmintic properties in vitro. Phytochemical screening reveals the presence of some secondary metabolites such as: polyphenols, flavonoids and condensed tannins. The toxicity study indicates that the triturated extract is not toxic in vitro on Artemia salina larvae with a lethal concentration greater than $0.1 \mathrm{mg} / \mathrm{ml}$. The success of purification tests of the extract would be more important to characterize the active ingredients for the properties recognized by breeders.
\end{abstract}

Copy Right, IJAR, 2019,. All rights reserved.

\section{Introduction:-}

Medicinal plants are considered to be a source of essential raw material for the discovery of new molecules needed for the development of future medicines (Kessoum, 2014). This justifies the increasing use of plants by population and more specifically breeders in the health management of their livestock. In Benin, the level of consumption of animal protein is $8.41 \mathrm{~kg} /$ person/year (MAEP, 2011), while FAO has estimated the normal consumption rate at 21 $\mathrm{kg} /$ person/year (DE, 2014). This low consumption may be due to either low population income and/or problems in the livestock subsector. Indeed, one of the major constraints faced by the livestock subsector in Benin is the pathologies related to gastrointestinal parasites (Hounzangbe-Adote et al., 2005) in particular H. contortus which causes serious parasitic disorder in the health of small ruminants. Thus, ensuring the empowerment of breeders and agro-breeders is tantamount to putting in place strategies to control these pathologies. These strategies are in most cases, based on conventional synthetic molecules that have come to show their limits (Olounladé et al., 2011). These limitations include not only the inaccessibility and high cost of these products, but also the counterfeiting and resistance developed by gastrointestinal parasites against these synthetic products. In the face of this problem, the 
search for alternative or complementary solutions to pest control is essential. Hence the use of plants potentially endowed with anthelminthic properties which today constitutes one of the most promising solutions that is environmentally friendly. This study therefore highlights the in vitro anthelinthic properties and larval toxicity of watery triturated extract from the leaves of $M$. inermis widely used in traditional medicine by small breeders in the control of gastrointestinal parasites of ruminants in general.

\section{Material and Methods:- \\ Plant material:-}

It consists of $M$. inermis leaves harvested in Zogbodomey in south Benin. This plant species is identified and authentified by the National Herbarium of Abomey-Calavi University with identification number AA 6713 / HNB.

\section{Extraction:-}

$50 \mathrm{~g}$ of $M$. inermis fresh leaves were crushed and recovered in $500 \mathrm{ml}$ of distilled water. After agitation and homogenization, the mixture is filtered on Wathman paper and the filter is concentrated in a rotary evaporator at a temperature between $55^{\circ} \mathrm{C}$ and $60^{\circ} \mathrm{C}$ with help of vacuum pump to obtain the extract. The dry, watery triturated extract obtained was stored in a refrigerator at $4^{\circ} \mathrm{C}$.

\section{Phytochemical Screening:-}

It is a qualitative chemical analysis. It was conducted on the watery triturated extract according to the standard method of Houghton and Raman (1998).

\section{Technique for inhibition of larval migration:-}

A larval migration inhibition (LMI) bioassay was used as described by Rabel et al. (1994) and used by HounzangbeAdote et al. (2005). $1000 / \mathrm{ml} \mathrm{L3s} \mathrm{larvae} \mathrm{were} \mathrm{put} \mathrm{in} \mathrm{contact} \mathrm{with} \mathrm{the} \mathrm{plant} \mathrm{extract} \mathrm{for} 3$ hours at $20^{\circ} \mathrm{C}$ at different concentrations $(1200,600,300$ and $150 \mu \mathrm{g} / \mathrm{ml})$ and the same procedure was repeated 3 times using the same concentration. After 3 hours, the L3s larvae were then rinsed 3 times by centrifugation and then migrated through mesh $20 \mu \mathrm{m}$ in diameter for 3 hours at a temperature of $23^{\circ} \mathrm{C}$. The larvae that migrated were taken up in a volume of $1.5 \mathrm{ml}$. The number of larvae was then counted in $200 \mathrm{ml}$. A negative control (PBS) and a positive control (levamisole $250 \mu \mathrm{g} / \mathrm{ml}$ ) were used to assess the migration of larvae in the absence of plants. The percentage inhibition of larval migration (LMI) was calculated using the following formula:

$$
\mathrm{LMI}=\frac{\mathrm{T}-\mathrm{M}}{\mathrm{T}} \times 100
$$

$\mathrm{T}$ is the total number of L3s deposited in the sieve and $\mathrm{M}$ the number of L3s present in the PBS.

\section{Technique for inhibiting the motility of adult worms:-}

The test was carried according to the method of Hounzangbe-Adote et al. (2005). For the collection of adult worms, immediately after sheep's death, the abomasum was removed delicately, opened and washed with saline solution at $37^{\circ} \mathrm{C}$. The collected and motility worms are each placed in $1 \mathrm{ml}$ of physiological liquid in NUNC plate wells, 24 wells, and placed in the oven at $37^{\circ} \mathrm{C}$. After one hour, $800 \mu \mathrm{l}$ of physiological fluid is removed and then replaced with the extract to be pre-tested in PBS at different concentrations (75, 150, 300, 600, 1200 and $2400 \mu \mathrm{g} / \mathrm{ml})$. A negative control (PBS) and a positive control (levamisole at 125, 250 and $500 \mu \mathrm{g} / \mathrm{ml}$ in PBS) are also formed. The test is repeated four times for each concentration and for controls. The motility of the worms is observed under the magnifying glass every 6 hours until all the worms contained in the PBS are immobile. The inhibition of the motility of adult worms in the treatments performed is used as the criteria of anthelminthic activity.

\section{Study of larval toxicity:-}

The interest of this study is the existing correlation between shrimp larvae and human cells (pulmonary cells, colon cells). It is a preliminary non-clinical toxicity test proposed by Michael et al. (1956) and later developed by Vanhaecke et $a l$. (1981) and Solis et al. (1993) and then used by Ahomadegbe et al. (2018). This test assesses the monitoring of larvae in the presence of the extract studied. In effect, the larvae of brine shrimp (Artemia salina) are obtained from the eggs of Artemia salina incubated for 48 hours in seawater taken from the Atlantic Ocean. Sixteen (16) larvae are put in contact with the pre-prepared test solution following a range of decreasing concentrations in 10 test tubes with a starting concentration of $50 \mathrm{mg} / \mathrm{ml}$. After 24 hours, the number of dead larvae in each tube is recorded. The lethal concentration $\left(\mathrm{LC}_{50}\right)$ was determined by looking at the graph showing the number of dead larvae based on different concentrations. The toxicity of the plant is assessed according to the match scale established by Mousseux (1995) (Table I). 
Table I:- Correspondence between $\mathrm{LC}_{50}$ and toxicity

\begin{tabular}{|l|l|}
\hline $\mathbf{L C}_{\mathbf{5 0}}$ & Correspondance toxicity \\
\hline $\mathrm{LC}_{50} \geq 0,1 \mathrm{mg} / \mathrm{ml}$ & $(-)$ No toxicity \\
\hline $0,1 \mathrm{mg} / \mathrm{ml}>\mathrm{LC}_{50} \geq 0,050 \mathrm{mg} / \mathrm{ml}$ & $(+)$ Low toxicity \\
\hline $0,050 \mathrm{mg} / \mathrm{ml}>\mathrm{LC}_{50} \geq 0,01 \mathrm{mg} / \mathrm{ml}$ & $(++)$ Moderate toxicity \\
\hline $\mathrm{LC}_{50}<0,01 \mathrm{mg} / \mathrm{ml}$ & $(+++)$ High toxicity \\
\hline
\end{tabular}

\section{Statistical analyzes:-}

The Excel spreadsheet was used to calculate averages, standard deviations of larval migration and to generate the illustration graphs. The different values were incorporated into a two-way repeated custom variance model. The comparison of the averages for the different tests was made using the SNK procedure that runs the Student test of the software R. The differences are considered significant at the $5 \%$ threshold.

\section{Results and Discussion:-}

\section{Extraction efficiency:-}

The watery triturated extract gave a low yield of $2.49 \%$. It is obtained by the ratio between the mass of the extract residue and the mass of the initial plant material.

\section{Phytochemical Screening:-}

Qualitative analysis of the different chemical groups present in the watery triturated extract of the leaves of $M$. inermis reveals firstly the presence of alkaloids, catechics tannins, flavones, leuco-anthocyans, quinonics compounds, mucilages and reducing compounds and secondly the absence of gallic tannins, anthocyanins, steroids, saponosides, cyanogenic derivatives and coumarins (Table II). These different secondary metabolites found in the watery triturated extract of the plant can confer on it the various pharmacological properties for which it is suspected.

Tables II:- The chemical compounds present in M. inermis extract.

\begin{tabular}{|l|l|}
\hline Groups & Watery triturated extract \\
\hline alkaloids & + \\
\hline tannins & + \\
\hline Catechics Tannins & + \\
\hline Gallicstannins & + (flavone) \\
\hline flavonoids & - \\
\hline anthocyans & + \\
\hline Leuco-anthocyans & + \\
\hline Quinonics coumpounds & - \\
\hline steroids & + \\
\hline Triterpenoïds & - \\
\hline saponosides & - \\
\hline Cyanogenics compound & + \\
\hline mucilage Pbsent & - \\
\hline coumarins & + \\
\hline Reducing compounds & \\
\hline Where: & \\
\hline
\end{tabular}

\section{Inhibition of larval migration:-}

The watery triturated extract of $M$. inermis leaves inhibits in vitro the migration of infesting larvae of $H$. contortus from the negative reference control, PBS ( $\mathrm{p}<0.001$ ) (Figure 1). The effect of this inhibition is not significant compared to the levamisol used as positive reference controls. However, it varies according to the dose of treatment ( $\mathrm{p}>0.05)$. The inhibitory action of the watery triturated extract is more noticed at low doses $(150 \mu \mathrm{g} / \mathrm{ml})$ and especially at the average dose of $300 \mu \mathrm{g} / \mathrm{ml}$ than at the high dose. The migration rate of larvae exposed to the extract is $60.05 \%$. 


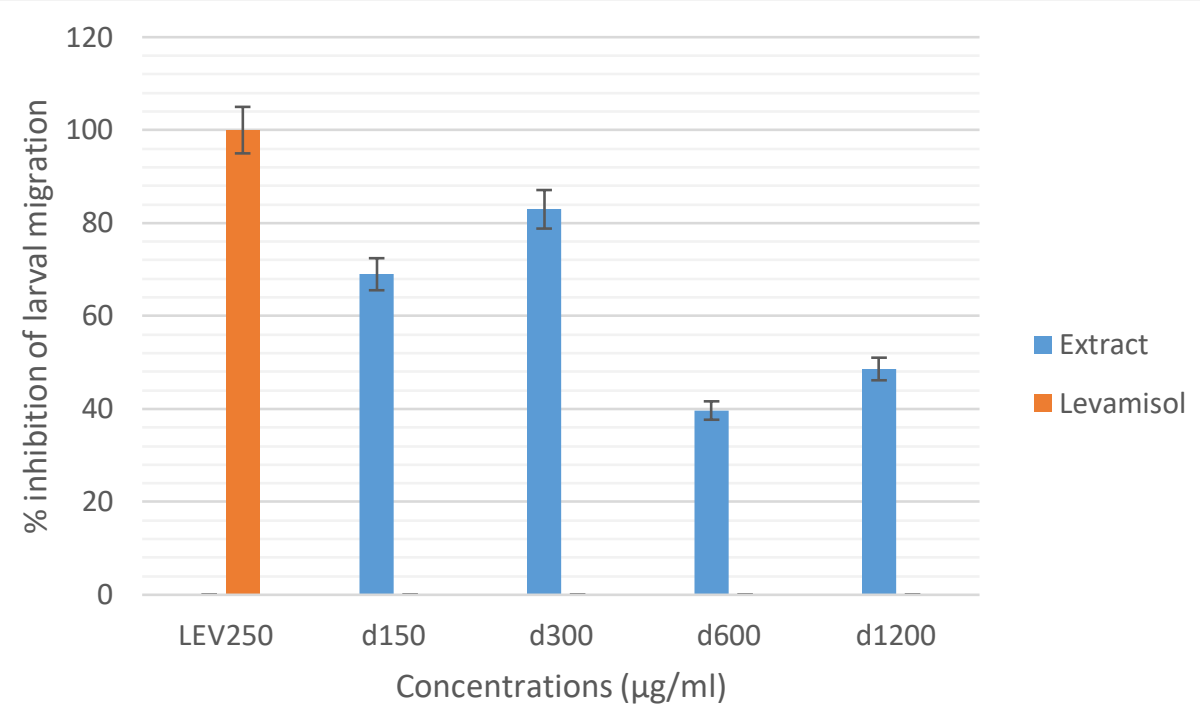

Figure 1:- Effects of watery triturated extracts on the motility of infective larvae of $H$. contortus.

Inhibition of the motility of adult worms:-

After 18 hours of exposure of the worms to watery triturated extract, almost all the worms were deprived of their motility, unlike the worms contacted with PBS, a negative reference which inhibited all the worms after 36 hours. As a result, the watery triturated extract from the leaves of $M$. inermis inhibits in vitro the motility of adult worms of $H$. contortus. This inhibition does not vary according to the dose of treatment $(\mathrm{p}>0.05)$ but varies according to time $(\mathrm{p}$ $<0.05$ ) (Table III).

Tables III:- Effects of different concentrations of $M$. inermis extract on $H$. contortus adult worms expressed as percentage of mobile worms in the wells.

\begin{tabular}{|l|c|c|c|c|c|c|c|}
\hline & Concentrations $(\mu \mathrm{g} / \mathrm{ml})$ & $6 \mathrm{~h}$ & $12 \mathrm{~h}$ & $18 \mathrm{~h}$ & $24 \mathrm{~h}$ & $30 \mathrm{~h}$ & $36 \mathrm{~h}$ \\
\hline PBS & 0 & 100 & 100 & 100 & 62.5 & 12.5 & 0 \\
\hline Lev & 125 & 37.5 & 0 & 0 & 0 & 0 & 0 \\
\hline & 250 & 62.5 & 0 & 0 & 0 & 0 & 0 \\
\hline & 500 & 87.5 & 0 & 0 & 0 & 0 & 0 \\
\hline Extract & 75 & 100 & 62.5 & 0 & 0 & 0 & 0 \\
\hline & 150 & 100 & 50 & 0 & 0 & 0 & 0 \\
\hline & 300 & 100 & 50 & 0 & 0 & 0 & 0 \\
\hline & 600 & 100 & 87.5 & 0 & 0 & 0 & 0 \\
\hline & 1200 & 100 & 37.5 & 0 & 0 & 0 & 0 \\
\hline & 2400 & 100 & 62.5 & 0 & 0 & 0 & 0 \\
\hline
\end{tabular}

\section{Larval toxicity :-}

The value of the lethal concentration for which $50 \%\left(\mathrm{LC}_{50}\right)$ of larvae died is determined from Figure 2.It appears that the $\mathrm{LC}_{50}$ of the triturated extract is $1.59 \mathrm{mg} / \mathrm{ml}$.

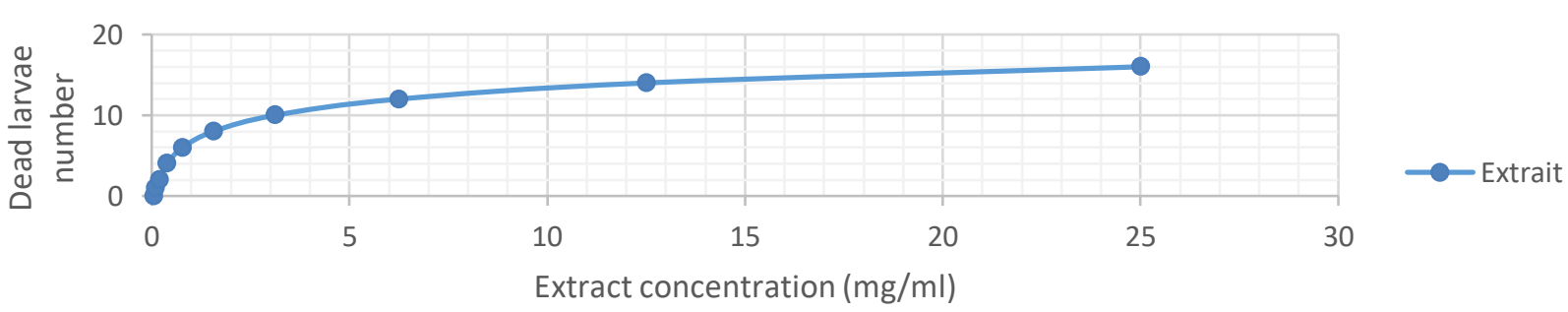

Figure 2:- Number of dead larvae as a function of the concentration of watery triturated. 


\section{Discussion:-}

Effective control of gastrointestinal nematodes in small ruminants today requires the discovery and synthesis of new, less costly and highly effective anthelminthic molecules. To achieve this, the purpose of this work is to evaluate in vitro the anthelminthic activity of the Mitragyna inermis plant cited in traditional medicine as possessing this property (Alowanou et al., 2015). Indeed, the leaves of this plant are widely consumed by ruminants as a drug plant. They are also combined with dietary supplements by breeders to help small ruminants resist helminthiasis (Alowanou et al., 2019). Fresh leaves can be used as a borehole for infested animals, they are directly used to prepare the sorted extract that was used for the various tests as part of this work. Ultimately, with a very low extraction yield, the watery triturated extract of $M$. inermis inhibited in vitro the migration of infesting larvae and the motility of adult worms of $H$. contortus. These results can be explained by the presence of secondary metabolites such as polyphenols, tannins and flavonoids present in this extract. Indeed, Martin et al. (2015) reported that tannins disrupted the installation of infectious larvae in sheep and goats and had a direct impact on the development of eggs into infectious larvae in faeces. As for Paolini. (2002), the anthelminthic filling of plant species would be contained in condensed tannins that effectively fight gastrointestinal parasitism and reduce parasite eggs in faeces. In addition, flavonoids inducestructural alterations in infesting larvae and prevent their migration (Brunet, 2008). Finally, Peltophorum africanum has shown in vitro anthelminthic activity which has been attributed to the presence of polyphenols (Bizimenyera et al., 2006). These families of compounds most often polar, is found in the watery triturated extract evaluate in this work. Extensive chemical studies are needed to identify the active ingredient responsible for the observed efficacy of $M$. inermis on $H$. contortus larvae and worms. In order to determine the tolerance limit of this plant, toxicity tests were carried out on the larvae of brine shrimp (Artemia salina). With $\mathrm{LC}_{50}$ greater than $0.1 \mathrm{mg} / \mathrm{ml}$, it follows that the extract is not toxic on the larvae of Artemia salina according to the match scale established by Mousseux (1995). Therefore, the M. inermis plant deserves to be valorised because it poses no danger of food poisoning for use in traditional medicine.

\section{Conclusion:-}

The watery triturated of the leaves of $M$. inermis plant given as fodder to the small ruminants, inhibits in vitro the migration of larvae and the motility of adult worms of $\mathrm{H}$. contortus. This property of the extract may be related to the presence of chemical groups such as tannins, flavonoids, alkaloids... suspected of this activity. Furthermore, the study of toxicity in vitro on the larvae of Artemia salina indicates the safety of this extract for its use in traditional medicine. Finally, further studies are needed to confirm the activity of the extract not only by in vivo tests, but also by seeking the active ingredient responsible for this property.

\section{Acknowledgements:-}

The authors mainly thank the West African Research Association (WARA) through the financed support granted to TOKLO Placide Mahougnan as part of Ideas Matter Doctoral Fellowship 2019 program. We thank also the Ministry of Higher Education and Scientific Research through the program supports PhD students

\section{References:-}

1. Ahomadegbe, M.A., Yayi-Ladekan, E., Togbenou, N., Assogba, F., Agbonon, A. and Gbenou, J. (2018): Phytochemical and toxicity studies of the leaves of Mangifera Indica, Cajanus cajanand of Piliostigma thonningii, acclimated in Benin, used against diarrheal disease. Journal of Pharmacognosy and Phytochemistry., 7(2): 2971-2978.

2. Alowanou, G.G., Olounlade, A.P., Azando, E.V.B., Dedehou, V.F.G.N., Daga, F.D. and Hounzangbe-adote, S.M. (2015): A review of Bridelia ferruginea, Combretum glutinosum and Mitragina inermis plants used in zootherapeutic remedies in West Africa: historical origins, current uses and implications for conservation. Journal of Applied Biosciences., 87: 8003-8014.

3. Alowanou, G.G., Olounladé, P.A., Akouèdegni, G.C., Faihun, A.M.L., Koudandé, D.O. and HounzangbéAdoté, S. (2019): In vitro anthelmintic effects of Bridelia ferruginea, Combretum glutinosum, and Mitragyna inermis leaf extracts on Haemonchus contortus, an abomasal nematode of small ruminants. Parasitology Research. Helminthology - Original Paper, p. 1-9.

4. Bizimenyera, E.S., Githiori, J.B., Eloff, J.N. and Swan, G.E. (2006): In vitro activity of Peltophorum africanum sond (Fabaceae) extracts on the Egg hatching and larval development of the parasitic nematode Trichostrongylus colubriformis. Vet. Parasitol., 142: 336-343. 
5. Brunet, S. (2008): Analyse des mécanismes d'action antiparasitaire de plantes riches en substances polyphénoliques sur les nématodes du tube digestif des ruminants. Thèse de Doctorat, Université Paul Sabatier de Toulouse, p. 246.

6. Direction de l'élevage. (2014): Rapport annuel. République du Bénin, p. 102.

7. Houghton, P.J. and Raman, A. (1998): Laboratory handbook for the fractionation of natural extracts. Chapman and hall, New York, p. 130-207.

8. Hounzangbe-Adote, M.S., Paolini, V., Fouraste, I., Moutairou, K. and Hoste H. (2005): In vitro effects of four tropical plants on three life-cycle stages of the parasitic nematode, Haemonchus contortus Research in Veterinary Science., 78: 155-160.

9. Kessoum, S. (2014): Activité antioxydante des polyphénols d'Artemisia herba alba. Diplôme de Master en Biologie, Option : Santé Publique. Université de Bejaia, République Algérienne Démocratique et Populaire, p. 72.

10. Martin, A., Potvin, A., Leboeuf, A., Lemieux, C. and Landry S. (2015): L'utilisation de tanins dans l'alimentation ovine pour prévenir le parasitisme. Revue de littérature, p. 37.

11. Michael, A.S., Thompson, C.G. and Abramovitz, M. (1956): Artemia salina as a test organism for a bioassay. Science., 123: 467-505.

12. Ministère de l'Agriculture de l'Elevage, de la Pêche (MAEP). (2011): Plan Stratégique De Relance Du Secteur Agricole (PSRSA), Cotonou, République du Bénin, p. 112.

13. Mousseux, M. (1995): Test de toxicité sur les larves de Artémia salina entretien d'élevage de balanes. Université française de Pacifique. Centre universitaire de Nouvelle Calédonie. Duest. Aquaculture.

14. Olounladé, P.A., Hounzangbé-Adoté, M.S., Azando, E.V.B., Tam Ha, T.B., Brunet, S., Moulis, C., Fabre, N., Fouraste, I. and Hoste H. (2011) : Valentin A. Etude in vitro de l'effet des tanins de Newbouldia laevis et de Zanthoxylum zanthoxylö̈des sur la migration des larves infestantes de Haemonchus contortus. Int. J. Biol. Chem. Sci., 5(4): 1414-1422.

15. Paolini, V., Dorchies, P. and Hoste, H. (2002): Effets des tanins condensés et des plantes à tanins sur les strongyloses gastro-intestinales chez le mouton et la chèvre. Unité Mixte Associée 1225 INRA/ENVT "Physiopathologie des Maladies infectieuses et Parasitaires des Ruminants". Toulouse, p. 3.

16. Rabel, B., McGregor, P. and Dough G. (1994): Improved bioassay for estimation of effects of ovine gastrointestinal inhibitory mucus and on nematode larval migration anthelminthic. International Journal of Parasitology., 24: 671-676.

17. Solis, P.N., Wright, C.W., Anderson, M.M., Gupta, M.P. and Phillipson, J.D. (1993): A microwell cytotoxicity assay using Artemia salina. Plant Med., 59: 250-252.

18. Vanhaecke, P., Persoone, G., Claus, C. and Sorgeloos, P. (1981): Proposal for a short-term toxicity test with Artemia nauplii. Ecotoxicol Env Safety., 5: 382-387. 